
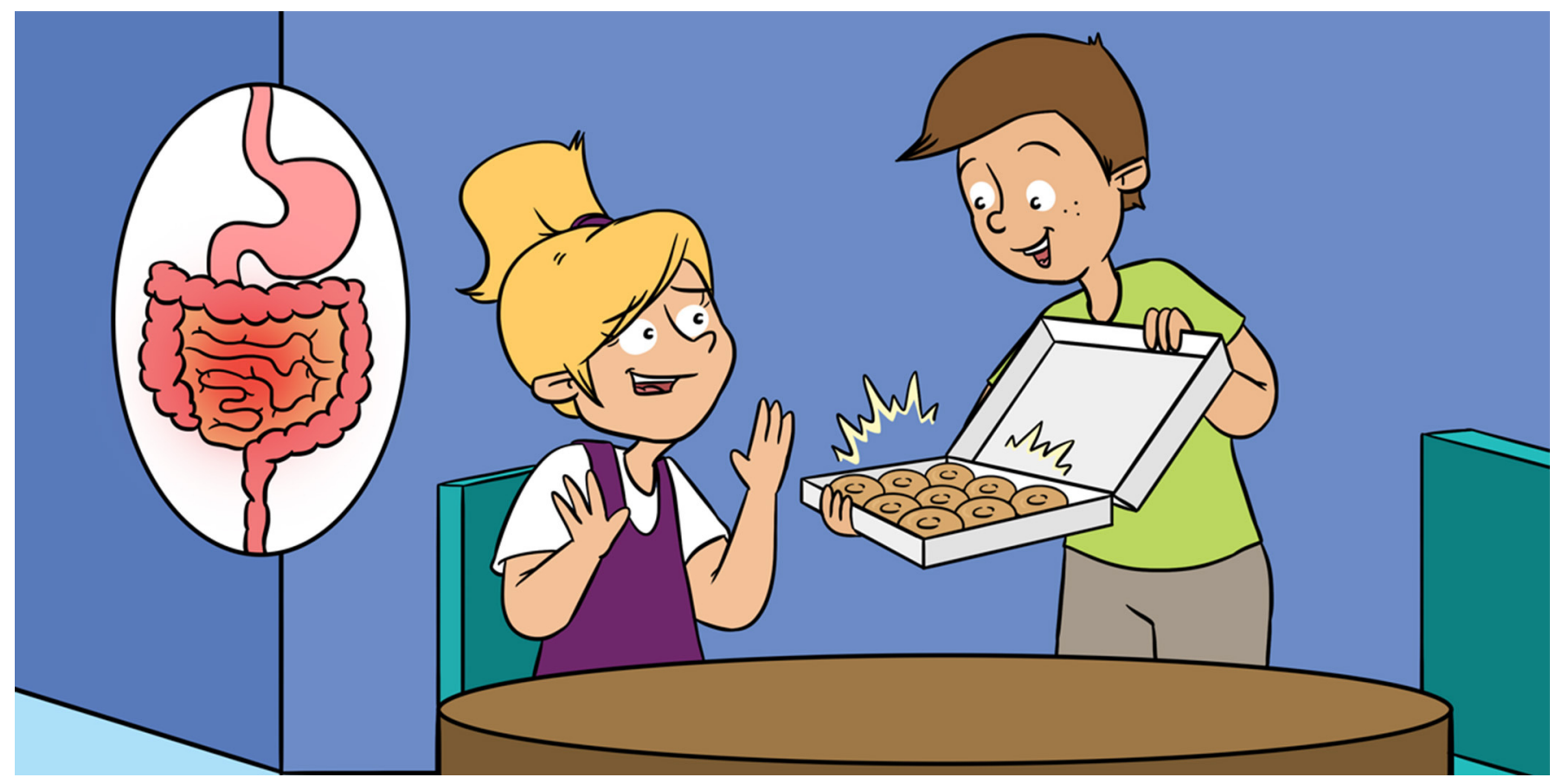

\title{
COELIAC DISEASE-WHAT IS IT AND HOW CAN PEOPLE DEAL WITH IT?
}

\section{Magdalena Osial ${ }^{1 *}$ and Agnieszka Pregowska ${ }^{2}$ \\ ${ }^{1}$ Faculty of Chemistry, University of Warsaw, Warsaw, Poland \\ ${ }^{2}$ Institute of Fundamental Technological Research, Polish Academy of Sciences, Warsaw, Poland}

YOUNG REVIEWER:

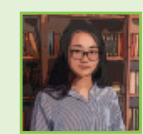

HAOYUN

AGE: 15
In recent years, you have likely heard that some people are eating gluten-free foods. Have you ever wondered why? Coeliac disease is one of the main reasons for this dietary choice. It affects people of all ages from all around the world. It is a genetic disorder that causes inflammation in the intestines and results in various symptoms that can be observed in other parts of the body. Unfortunately, people often ignore coeliac disease or treat it like a simple allergy. Some people may view gluten-free dietary choices as just a trend. Some food allergies can manifest like coeliac disease, but these have different causes. Coeliac disease should be taken seriously, because it may not only lead to life-threatening symptoms, but also have a chronic impact on health and quality of life.

\section{WHAT IS COELIAC DISEASE?}

Our bodies have various systems that work together, such as the cardiovascular, nervous, and digestive systems. The main purpose 


\section{ANTIBODY}

A protein produced by the immune system to bind to and neutralize microorganisms during an infection.

\section{B CELLS}

Cells of the immune system that produce antibodies.

\section{COELIAC DISEASE}

Autoimmune disorder where the body (autoimmune system) abnormally reacts when you eat gluten. It mainly affects its own tissues in the gut. When the tissues in the gut are damaged, the body cannot properly absorb nutrients from food.

\section{VILLI}

Tiny, finger-shaped tissues in the intestines that absorb nutrients from food.

\section{AUTOIMMUNE RESPONSE}

Natural body reaction (immune system response) when it senses danger like viruses, bacteria, or foreign substances that can be harmful. It is a defense reaction to invaders protecting the body.

\section{INFLAMMATION}

The body's rapid response to any kind of insult or injury caused by microorganisms, radiation, heat, chemical toxins, foreign objects, or physical wounds. of the digestive system is to allow the body to get nutrients from food. To stay healthy, the digestive system must cooperate with the immune system, which is responsible for defending the body from dangerous microorganisms. One way that the immune system defends us is by the production of chemical and biological substances, such as antibodies. Antibodies are produced by cells called B cells, and they are made when the body recognizes that it is being attacked by microorganisms.

Sometimes the immune system does not work properly. It may overreact and produce too many antibodies, which then act like a furious army without a general, attacking everything around them-not only dangerous invaders, but also healthy tissue. This is exactly what happens when a person with coeliac disease eats gluten.

\section{WHAT EXACTLY IS GLUTEN?}

Gluten is a group of related proteins naturally found in grains like barley, wheat, and rye. Gluten proteins give dough made from grains its stretchy, elastic quality. Gluten acts like glue; it allows the components of cake or bread to stick together more easily. Since gluten proteins are commonly a part of our foods, they should not have a negative influence on our bodies.

When we eat a protein like gluten, our bodies transport gluten from the stomach to the small intestine. There, digestive enzymes cut gluten (and other proteins) into smaller pieces, called peptides. Unfortunately, some people cannot consume gluten at all. When they eat a tiny piece of bread, cake, or other food containing even traces of gluten, the small pieces of chopped up gluten activate the immune system, which overreacts in a way that is destructive to healthy tissue. When someone suffers from coeliac disease, gluten peptides are recognized incorrectly as foreign substances by the immune system's B cells. The $B$ cells then produce antibodies that attack healthy intestine tissues called villi, rather than fight real threats to the body [1].

This kind of reaction, in which the immune system attacks the body instead of foreign invaders, is called an autoimmune response. It results in a process called inflammation. Inflammation causes the destruction of villi, which are responsible for the absorption of nutrients (see Figure 1). After each "attack," a person with coeliac disease becomes weaker, due to permanent inflammation and a lack of critical nutrients, such as carbohydrates, proteins, fatty acids, minerals, and vitamins. The inflammation and nutrient deficiency can cause other health problems, and may increase the risk of other diseases and food intolerances [2] (see Figure 2). 


\section{Figure 1}

The lower digestive tract. The small intestine lies below the stomach and is the area most commonly affected by coeliac disease. The role of the small intestine is the digestion of food through chemical reactions involving digestive enzymes, and the absorption of nutrients through the villi.

\section{Figure 2}

The small intestine wall has four layers, and the innermost layer is covered with tiny, finger-shaped structures called villi. The blood circulating in the villi absorbs nutrients from digested food. Villi affected by coeliac disease are damaged by inflammation and absorb fewer nutrients than healthy villi. This causes deficiencies that affect the whole body.
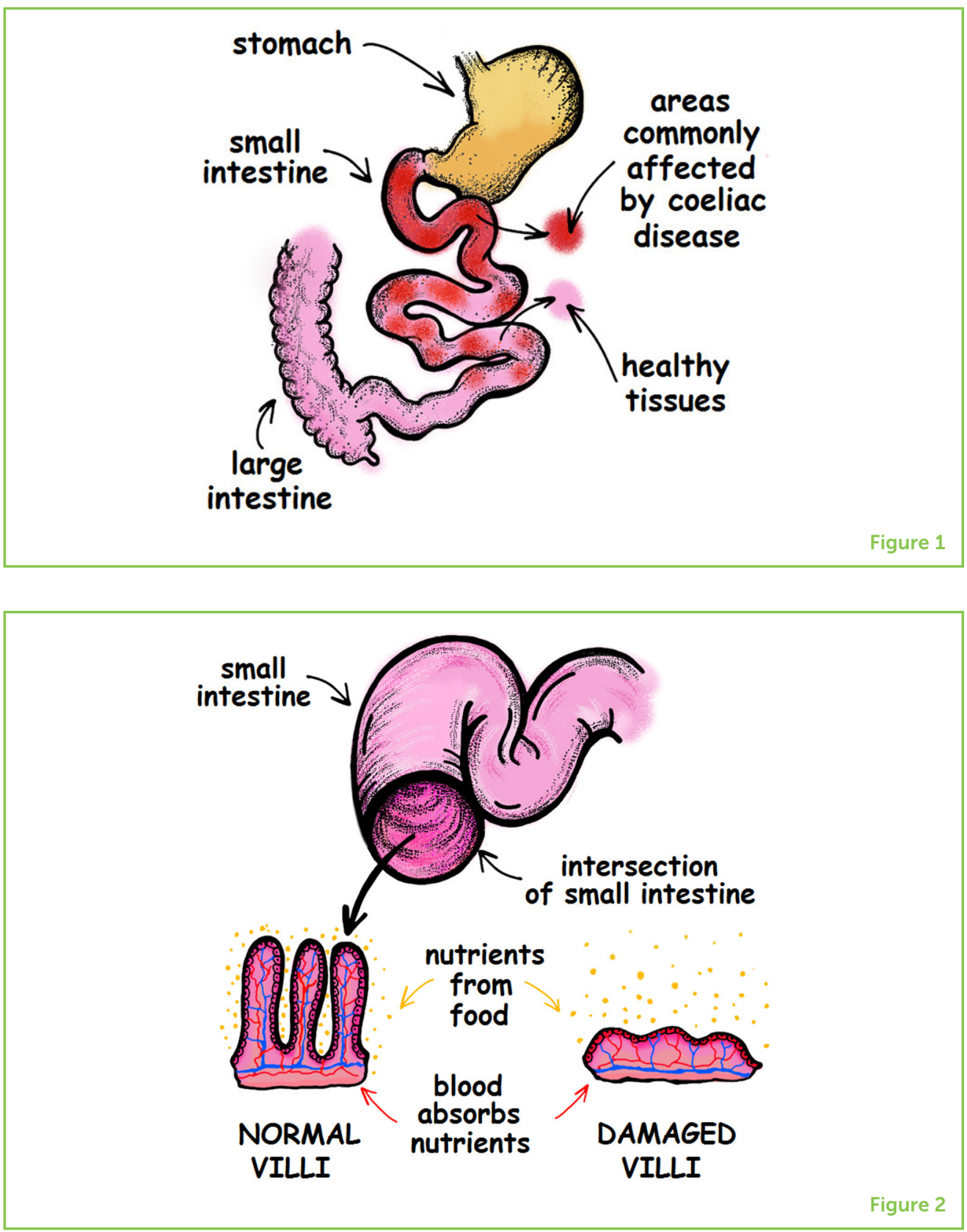

Damage to villi also causes intolerance of dairy products containing lactose. Lactose is a natural sugar produced in milk, which is normally digested by an enzyme called lactase. Lactase is produced in the villi tissue, so if the villi are damaged, lactose cannot be digested. This results in a number of gastric symptoms, like gas and flatulence.

\section{WHAT ARE THE SYMPTOMS OF COELIAC DISEASE?}

Symptoms of coeliac disease can also vary from person to person. The main symptoms include vomiting, nausea, and abdominal pain after eating gluten-containing foods. Some people may also have headaches, bone and joint pain, diarrhea, or tiredness; others may 


\section{GLUTEN-FREE} FOOD

Food containing traces of gluten smaller than $20 \mathrm{mg}$ per $1 \mathrm{~kg}$, or food that does not naturally contain gluten. have skin rashes, weight loss or gain, bloating, constipation, or even anemia. Sometimes symptoms occur alone, and sometimes together. Everyone with coeliac disease may react differently to gluten. Thus, it is extremely difficult to diagnose coeliac disease, especially in those who do not have digestive problems directly after consuming foods containing gluten [3].

To make things even more complicated, coeliac disease symptoms may be very aggressive, moderate, mild, or even non-existent. Since the degree of symptoms is so variable, some people may never be accurately diagnosed with coeliac disease during their lifetimes.

\section{IMPORTANCE FOR CHILDREN AND TEENS}

Coeliac disease affects people worldwide, including kids and teenagers. To emphasize the problem, we should look at an example. Imagine a school of 100 children; in this group, at least one person will have coeliac disease. Early diagnosis is essential for preventing kids from developing the serious health problems that can result from long-term gluten consumption. Coeliac disease is a genetic disorder, meaning that people get it because they have inherited certain genes. So it is important to explain to children that coeliac disease will be with them for their entire lives, and they will need to follow a strict gluten-free diet to reduce potential side effects [4].

\section{CAN COELIAC DISEASE BE CURED?}

Coeliac disease cannot be cured yet. The only known cure known at this time is a gluten-free diet. Even a small piece of food containing gluten can cause serious problems for those with coeliac disease, so the only option is to avoid all foods containing gluten. Since coeliac disease is a genetic disorder and not an allergy, unfortunately it has no chance of disappearing during a person's lifetime. Damaged villi tissue recovers very slowly and sometimes needs even a few years to get better.

Here are a few dietary recommendations that should be followed by people with coeliac disease:

- Avoid spicy foods, because they can irritate villi tissue. This is especially important for people who have been recently diagnosed with coeliac disease.

- Bake bread, cake, or pizza in a separate gluten-free-use oven, make toast in a separate gluten-free-use toaster, and chop food on separate gluten-free-use chopping boards.

- Avoid foods with even traces of gluten. For example, if the chocolate of one producer contains gluten, it is likely that all products from the same producer contain traces of gluten. 
- Keep a balanced diet full of fresh vegetables, fruits, fish, and meat, to provide the body with necessary nutrients like calcium, iron, fiber, and omega-3 fatty acids.

\section{CONCLUSIONS}

Coeliac disease is a serious autoimmune disorder that affects people of all ages. It is characterized by a complicated set of symptoms, and it may be challenging to diagnose because the symptoms are not very unique or specific. The only cure known that we currently have is a gluten-free diet. Ignoring or failing to diagnose the disease can lead to additional serious health problems. However, if people with coeliac disease completely avoid gluten and follow a few other strict rules concerning nutrition, their villi can heal and they can live normal lives.

\section{AUTHOR CONTRIBUTIONS}

$\mathrm{MO}$ and AP: conceptualization and methodology. $\mathrm{MO}$ : original manuscript writing and review. AP: original manuscript writing and editing.

\section{REFERENCES}

1. Sabatino, A. D., and Corazzo, G. R. 2009. Coeliac disease. Lancet 373:1480-93. doi: 10.1016/S0140-6736(09)60254-3

2. Sollid, M. L. 2002. Coeliac disease-dissecting a complex inflammatory disorder. Nat. Rev. Immunol. 2:647-55. doi: 10.1038/nri885

3. Singh, P., Arora, A., Strand, T. A., Leffler, D. A., Catassi, C., Green, P. H., et al. 2018. Global prevalence of celiac disease: systematic review and meta-analysis. Clin. Gastroenterol. Hepatol. 16:823-36. doi: 10.1016/j.cgh.2017.06.037

4. Mellini, V., and Mellini, F. 2019. Gluten-free diet: gaps and needs for a healthier diet. Nutrients 11:170. doi: 10.3390/nu11010170

SUBMITTED: 26 April 2020; ACCEPTED: 20 May 2021;

PUBLISHED ONLINE: 22 June 2021.

EDITED BY: Valeria Costantino, University of Naples Federico II, Italy

CITATION: Osial M and Pregowska A (2021) Coeliac Disease-What Is it and How Can People Deal With it? Front. Young Minds 9:555959. doi: 10.3389/frym.2021. 555959

CONFLICT OF INTEREST: The authors declare that the research was conducted in the absence of any commercial or financial relationships that could be construed as a potential conflict of interest. 


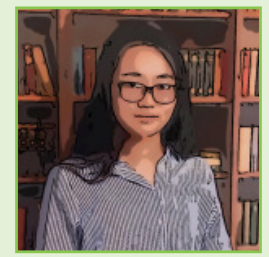

COPYRIGHT @ 2021 Osial and Pregowska. This is an open-access article distributed under the terms of the Creative Commons Attribution License (CC BY). The use, distribution or reproduction in other forums is permitted, provided the original author(s) and the copyright owner(s) are credited and that the original publication in this journal is cited, in accordance with accepted academic practice. No use, distribution or reproduction is permitted which does not comply with these terms.

\section{YOUNG REVIEWER}

\section{HAOYUN, AGE: 15}

Hi! I am Haoyun, 15, and enjoy reading about various social sciences or playing piano in my spare time.

\section{AUTHORS}

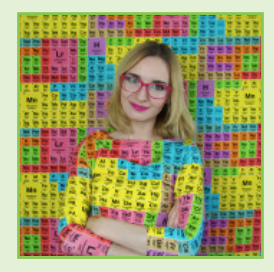

\section{MAGDALENA OSIAL}

Magdalena Osial is a scientist from the University of Warsaw. Her research focuses on the synthesis and application of nanomaterials for medicine and industry. She is a chemist and collaborates with scientists from various fields working on different interdisciplinary projects, including electrochemical sensors, medical diagnostics, and engineering. Her passion is science popularization, so she enjoys science workshops for kids when she is not in the laboratory. She also spends her free time hiking, drawing, board games, and playing old-school PC games. *mosial@chem.uw.edu.pl

\section{AGNIESZKA PREGOWSKA}

Agnieszka Pregowska is a scientist from the Institute of Fundamental Technological Research Polish Academy of Sciences. Her research is focused on biomedical signal processing, neuroinformatics, and the application of augmented reality in medicine. She is an engineer working on various signal types. She collaborates with scientists from the fields of medicine, biophysics, bioengineering, computer science, statistics, and informatics to provide the insights to personalized medical diagnostics. She enjoys traveling, long-distance cycling, dancing, and motorization. 